\title{
Lectotypification of six names in the genus Sida (Malvaceae)
}

\author{
Nimbalkar V.V. ${ }^{1}$, Tambde G.M. ${ }^{2}$ \& M.M. Sardesai ${ }^{1 *}$ \\ ${ }^{1}$ Department of Botany, Savitribai Phule Pune University, Pune, Maharashtra - 411 007, India \\ ${ }^{2}$ Department of Botany, Shri. Vyankatesh Arts, Commerce and Science College, Deulgaon Raja, Maharashtra - 443 204, India \\ ${ }^{\star}$ E-mail: sardesaimm@gmail.com
}

\begin{abstract}
Six names in Sida L., viz., S. cuneifolia Roxb., S. mysorensis Wight \& Arn., S. ovata Forssk., S. repens Dombey ex Cav., S. scabrida Wight \& Arn. and $S$. schimperiana Hochst. ex A.Rich. are lectotypified here. Of these names, S. mysorensis Wight \& Arn. and S. schimperiana Hochst. ex A.Rich. involve second-step lectotypification.
\end{abstract}

Keywords: India, Lectotypes, Malvaceae, Sida, Typification.

\section{Introduction}

The genus Sida L. was established by Linnaeus (1753) to include ten species, of which four, viz., S. spinosa L., S. rhombifolia L., S. alnifolia L. and S. cordifolia L. are now retained in Sida: two species in Wissadula Medik. and one each in Abutilon Mill., Herissantia Medik., Anoda Cav. and Malachra L. Sida is one of the largest genera in the family Malvaceae, and distributed mainly in tropical and subtropical regions of the world with $c .250$ species (Mabberley, 2017; POWO, 2019). Paul and Nayar (1988) and Paul (1993) reported 12 species of Sida from India, subsequently Sivarajan and Pradeep (1996) recorded 17 species from southern Peninsular India. Two new species were described by Tambde et al. $(2016,2020)$ while the occurrence of $S$. angustifolia Medik. in India is discussed by Gavade et al. (2020). With these reports, the genus is represented by 22 species in India. In the present paper lectotypes are

Received: 21.09.2020; Revised \& Accepted: 19.03.2021

Published Online: 30.06.2021 designated for six names in Sida, viz., S. cuneifolia Roxb., S. mysorensis Wight \& Arn., S. ovata Forssk., S. repens Dombey ex Cav., S. scabrida Wight \& Arn. and S. schimperiana Hochst. ex A.Rich. in accordance with the ICN (Turland et al., 2018) after having consulted the original material.

\section{Typification}

Sida cuneifolia Roxb., Fl. Ind. 3: 170. 1832.

Lectotype (designated here): Sida cuneifolia Roxb. drawing in Icones Roxburghianae no. 341 (K digital image!).

Fig. 1

Notes: The name S. cuneifolia was proposed by Roxburgh (1832), in 'Flora Indica'. According to Stafleu and Cowan (1983) Roxburgh's specimens and types are known to be placed at BM, BR, E, G, $\mathrm{K}$ and LIV; small set at B (Willd), C, DBN, E, FI, NY, OXF, P, PH, UPS (Thunb.). Stafleu and Cowan (1983) also stated that Roxburgh's drawings are of great importance for the typification of Roxburgh's species. As Roxburgh's collection or specimens referred for description could not be traced for the name S. cuneifolia, Roxburgh's drawing with 'Roxburgh number 341' is referred to study as an original material which depicts the characters mentioned in the protologue, and it is designated here as lectotype.

Sida mysorensis Wight \& Arn., Prodr. Fl. Ind. Orient. 1: 59. 1834.

Lectotype (first-step designated by Borssum, 1966; second-step designated here): INDIA, Karnataka, Mysore, 14.05.1800, Неуnе 183 (K [K000659370 


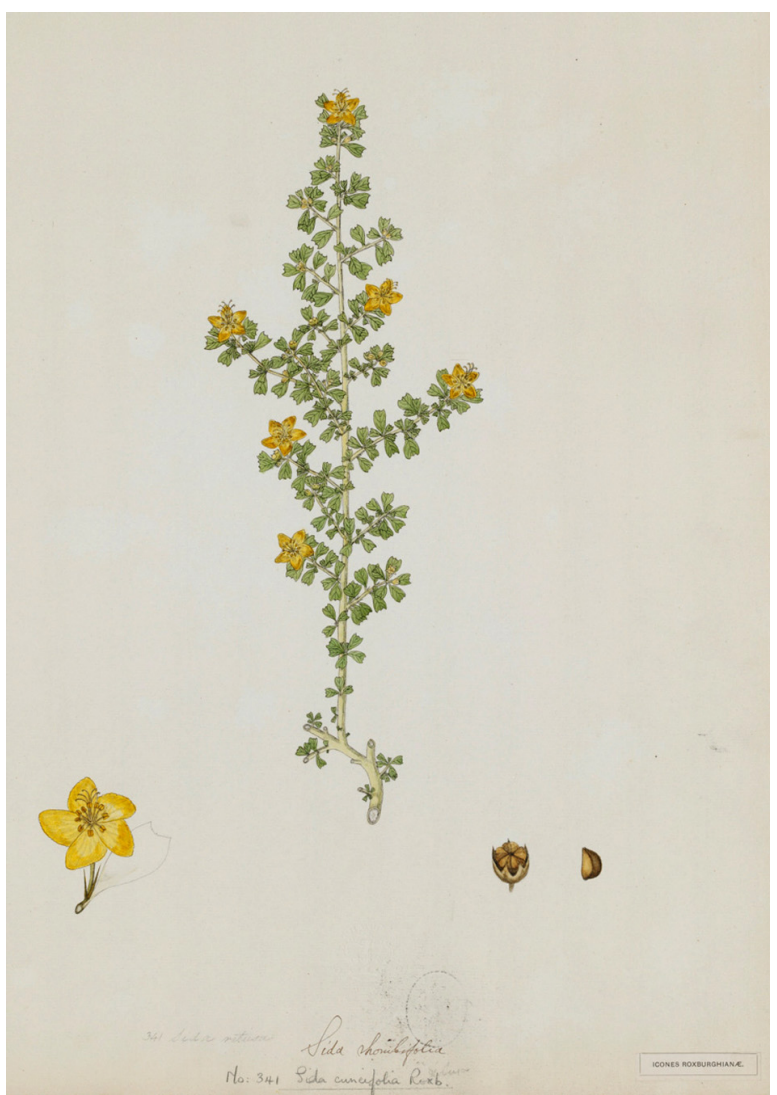

Fig.1. Lectotype of Sida cuneifolia Roxb. drawing in Icones Roxburghianae no. 341 (K) (http://apps.kew.org/floraindica/img/ illustration/large/23372.jpg) (C) Copyright of the Board of Trustees of the Royal Botanic Gardens, Kew. Reproduced with permission.

digital image!]; isolecto K [K000659371 digital image!]).

Fig. 2

Notes: Wight and Arnott (1834) described S. mysorensis based on collections by different collectors. They can be considered as syntypes. Among which, Borssum (1966) cited Wight's specimen with number ' 183 ' which is from Heyne's herbarium as mentioned by Noltie (2005) and connected to Wallich catalogue no. 1855. Two sheets of Heyne's collection from Mysore are housed at K, one with number ' 183 ' and the other without a number, but the date of collection $\left(14^{\text {th }}\right.$ May, 1800) for both specimens indicates that the specimens are part of a single gathering. Moreover, the sheet with number ' 183 ' has two specimens mounted on it with two different barcode numbers (K000659370, K000659371). One of them (K000659370) is designated here as the second-step lectotype considering the type

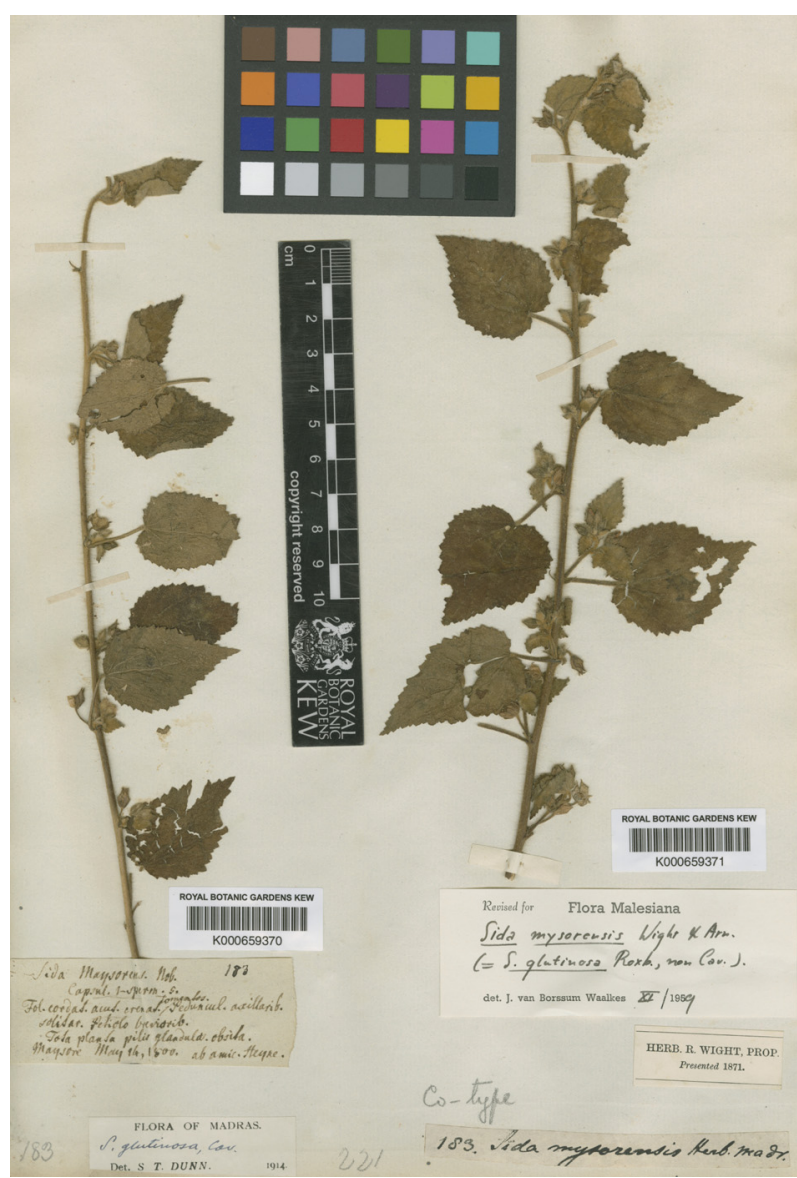

Fig. 2. Lectotype of Sida mysorensis Wight \& Arn. (K000659370 http://specimens.kew.org/herbarium/K000659370) (C) Copyright of the Board of Trustees of the Royal Botanic Gardens, Kew. Reproduced with permission.

citation by Borssum (1966) as a first-step lectotypification.

Sida ovata Forssk., Fl. Aegypt.-Arab. 124. 1775.

Lectotype (designated here): ARABIA, Surdud, February 1763, P. Forsskal 1728 (C [C10003059 digital image!]).

Fig. 3

Notes: Forsskal (1775) in the protologue cited his collection from Surdud, Arabia. Two relevant specimens could be traced at C (C10003059, C10003061) and one at BM (BM000603910). Of those, $\mathrm{C} 10003059$ with fruits is designated here as the lectotype. The specimen is determined as 'proposed lectotype' by O.A. Leistner in May, 1967, but this has not been seen as published so far and this cannot be considered as effective publication (Art. 7.10 of ICN, Turland et al., 2018). 


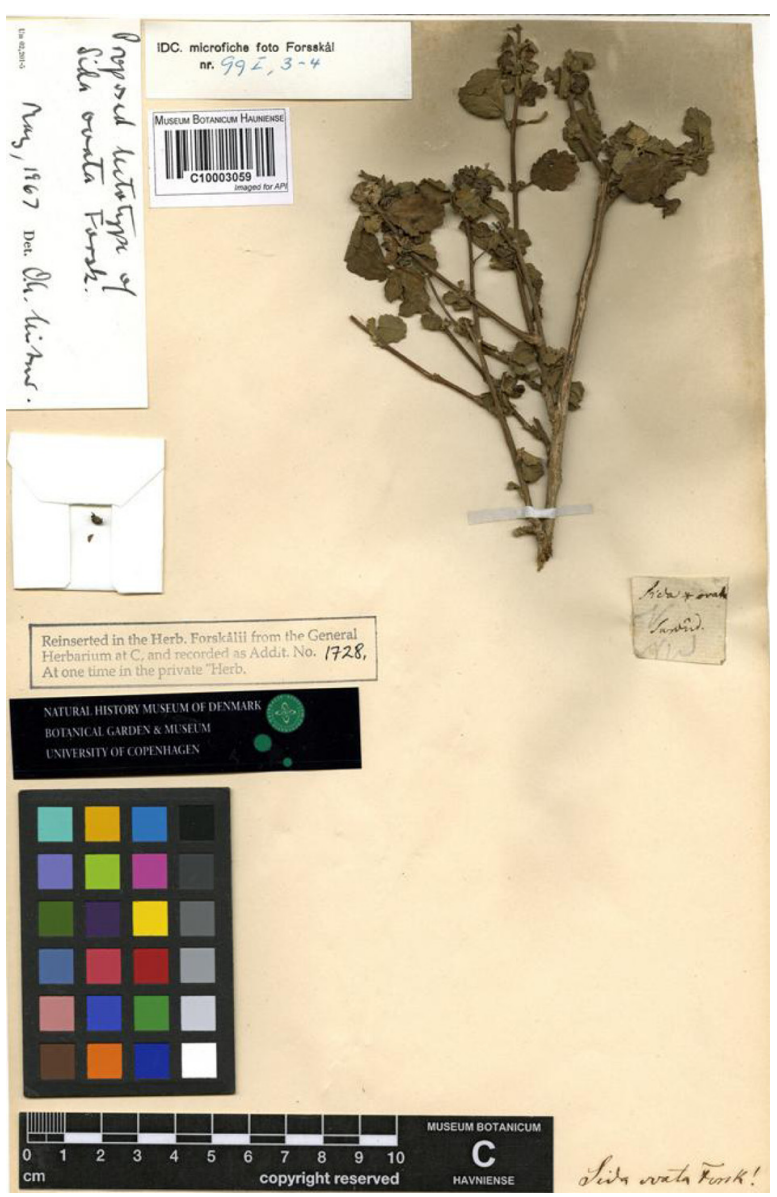

Fig. 3. Lectotype of Sida ovata Forssk. (C10003059 http:// digit.snm.ku.dk/www/ctyp/full/C10003059.jpg) (C Copyright of the Natural History Museum of Denmark, University of Copenhagen. Reproduced with permission.

Sida repens Dombey ex Cav., Diss. 1, Diss. Bot. Sida 7. 1785.

Lectoype (designated here): PERU, s.l., Dombey J. s.n. (MA [MA656279 digital image!]).

Fig. 4

Notes: The herbarium and types of Cavanilles are at MA, and many of his names are based on specimens in P, P-LA, and P-JU (Stafleu and Cowan, 1976). As the name $S$. repens is published based on Dombey's collection, search for the specimen was attempted in MA as well as P. Two specimens of $S$. repens collected by Dombey at $\mathrm{P}$ could be traced which matches well with the protologue description. Moreover, one specimen (MA-656279) from 'Cavanilles Type collection' section was found at MA and as per the discussion with Eva Garcia Ibanez, Curator of the herbarium,

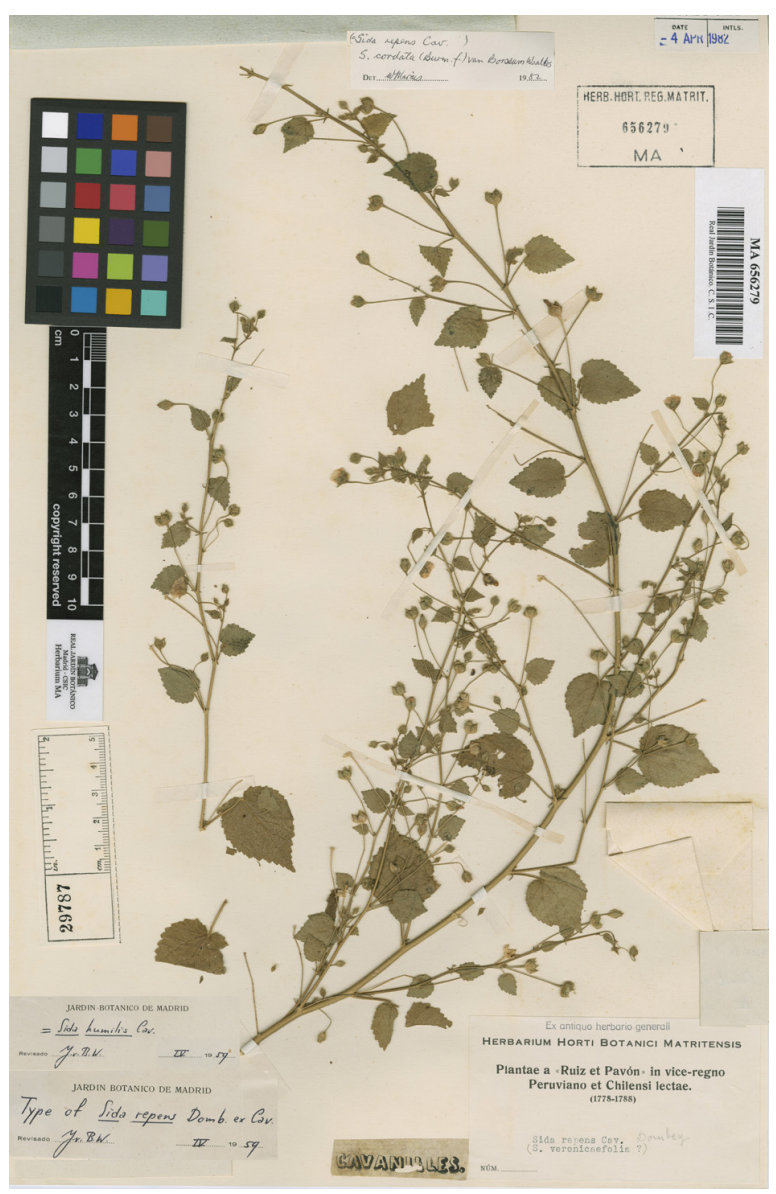

Fig. 4. Lectotype of Sida repens Dombey ex Cav. (MA656279 http:// 161.111.171.57/herbarioV/visorVCat.php?img=MA-01-00656279) (C) Copyright of the MA Herbarium, Real Jardín Botánico Madrid. Reproduced with permission.

Joseph Dombey was part of Ruiz \& Pavon's expedition to Peru, which took place between 1778 and 1788. Some of the herbarium specimens of this expedition were taken out by Cavanilles in order to create his separate 'Type collection'. With this in mind, the specimen which is part of 'Cavanilles type collection' is selected here as lectotype.

Additionally, the specimen (MA-656279) bears the number '29787' on a small label, which was added to the specimen at the beginning of the $20^{\text {th }}$ century, when it was on loan to the Field Museum (USA). The number '29787' was used in some publications (Fryxell, 1985) and electronic database (Tropicos), but it is added to the sheet when the specimens was lodged and renumbered at the Field Museum (USA), and it is neither a 'collection 
number' nor an accession number or barcode number added by MA.

Sida scabrida Wight \& Arn., Prod. Fl. Ind. Orient. 1: 57.1834.

Lectotype (designated here): INDIA, Tamil Nadu, (Madras), s.d., Wight 198 (K [K000659357 image!]).

Fig. 5

Notes: A specimen at K (K000659357), part of the Wight Herbarium is identified as type material of the name Sida scabrida Wight \& Arn., supported by Wight's catalogue No. 198 as mentioned in the protologue and it precisely matches with it. Therefore, the specimen is designated here as lectotype. Sivarajan and Pradeep (1994) cited the type of S. scabrida as 'Wight 166', but the specimen cited in the protologue is 'Wight! cat. $n$. 198' and

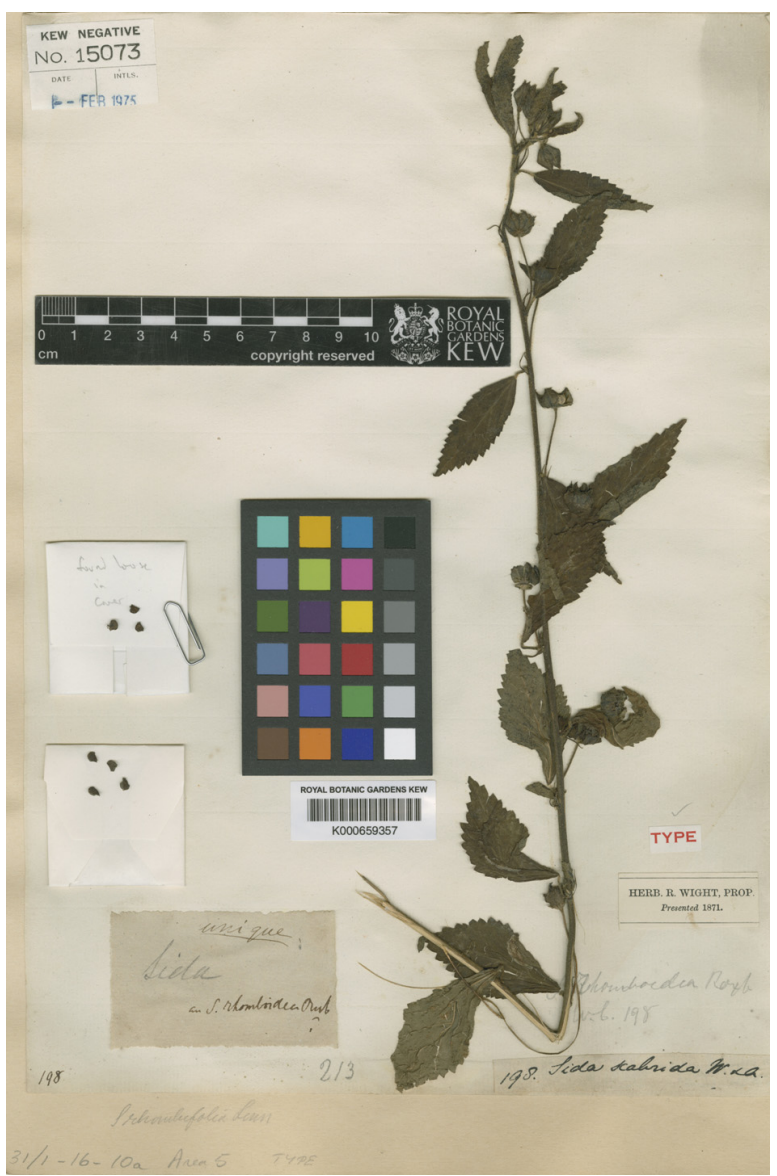

Fig. 5. Lectotype of Sida scabridaWight \& Arn. (K000659357 http:// specimens.kew.org/herbarium/K000659357) (C) Copyright of the Board of Trustees of the Royal Botanic Gardens, Kew. Reproduced with permission. should only serve as type material. Noltie (2005) also noted that the type material for this name is 'WC 198'. He also commented that he could not trace a specimen at K. However, the specimen referred to in the protologue was traced at $\mathrm{K}$ and an image of the same is provided here.

Sida schimperiana Hochst. ex A.Rich., Tent. Fl. Abyss. 1: 66. 1847.

Lectotype (first-step designated by Vollesen, 1986; second-step designated here): ABYSSINIA (Ethiopia), 04.06.1837, G.H.W. Schimper 282 (P [P00761807 digital image!]).

Fig. 6

Notes: While describing Sida schimperiana, Richard (1847) cited collections of G.H.W. Schimper, Richard Quartin-Dillon and Anton Petit in the protologue. Vollesen (1986) inadvertently

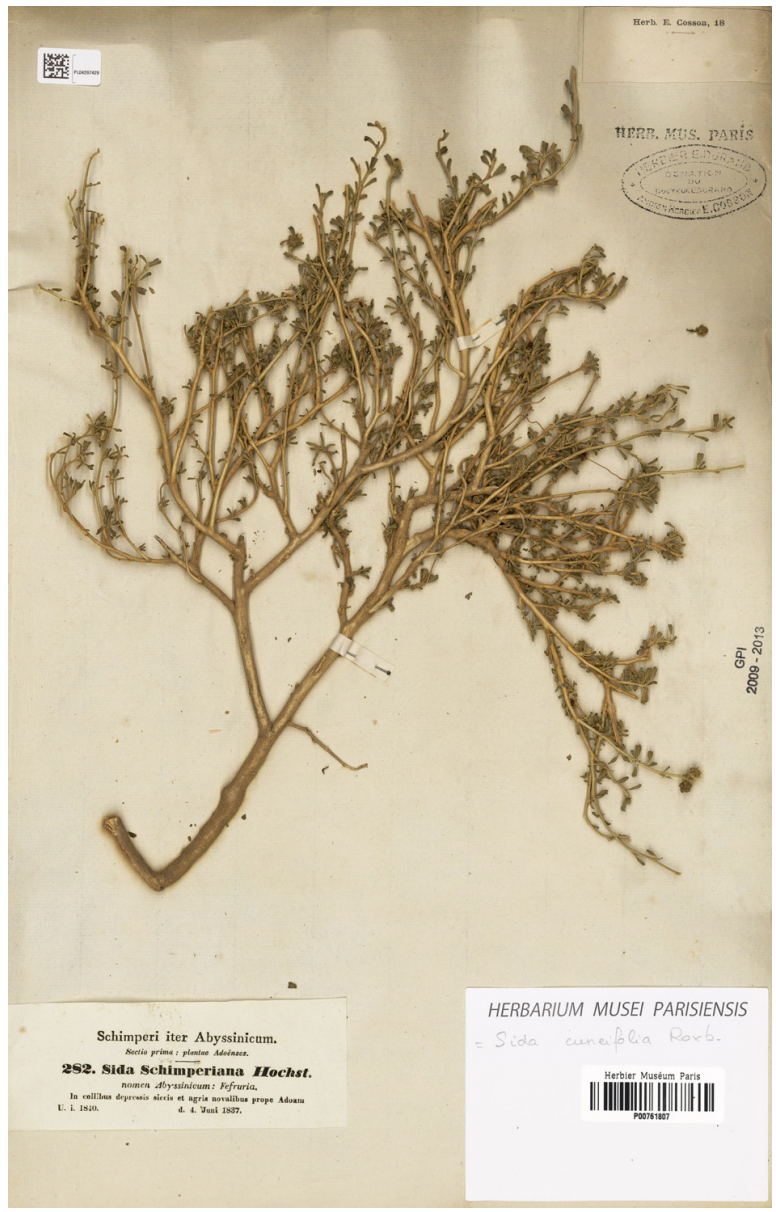

Fig. 6. Lectotype of Sida schimperiana Hochst. ex A.Rich. (MNHN-PP00761807 http://coldb.mnhn.fr/catalognumber/mnhn/p/p00761807) (C) Copyright of the Muséum National d'Histoire Naturelle, Paris. Reproduced with permission. 
lectotypified the name (Art. 7.11 of ICN, Turland et al., 2018) by citing Schimper's collection at $\mathrm{P}$ as the type. There are five such relevant specimens at $\mathrm{P}$ (viz., P00761802, P00761804, P00761805, P00761806 and P00761807, of the same gathering Schimper 282) and it cannot be ascertained which particular specimen was designated as lectotype. Thus, we have considered the type citation of Vollesen (1986) as first-step lectotypification and one of the specimens (P00761807) is designated here as the second-step lectotype, which bears fruit and a label indicating the specimen from Schimper's herbarium.

\section{Acknowledgements}

We are thankful to the authorities of herbaria (BM, BR, C, CAL, E, G, K, LIV, MA, OXF, P) consulted for the information provided. We also thank the Head, Department of Botany, Savitribai Phule University, Pune and Principal, Shri. Vyanktesh Arts Commerce and Science College, Deulgaon for providing necessary facilities. VVN and MMS are grateful to RUSA-MHRD, Government of India, for financial assistance. Authors also express gratitude to anonymous reviewers for important comments which helped to improve the manuscript.

\section{Literature Cited}

FORSSKAL P. 1775. Flora Aegyptiaco-Arabica. Hauniae (Copenhagen): ex officina Mölleri.

FRYXELL P.A. 1985. Sidus sidarum - V. The North and Central American species of Sida. Sida 11(1): 62-91. https://www.jstor.org/stable/23909127

GAVADE S.K., NIMBALKAR V., LEKHAK M.M. \& M.M. SARDESAI 2020. Identity, occurrence and typification of Sida angustifolia (Malvaceae), a neglected species in India. Annales Botanici Fennici 57: 279-284. https://doi.org/10.5735/085.057.0411

LINNAEUS C. 1753. Species Plantarum. Volume 2. Impensis Laurentii Salvii, Stockholm.

MABBERLEY D.J. 2017. Mabberley's Plant-Book: a portable dictionary of plants, their classification and uses. Fourth Edition. Cambridge University Press, Cambridge.

NOLTIE H.J. 2005. The Botany of Robert Wight. Regnum Vegetabile 145. A.R.G. Gantner Verlag, Ruggell.

PAUL T.K. 1993. Malvaceae. In: SHARMA B.D. \& M. SANJAPPA (eds.), Flora of India. Volume 3. Botanical Survey of India, Kolkata. pp. 257-394.
PAUL T.K. \& M.P. NAYAR 1988. Malvaceae. In: NAYAR, M.P., THOTHATHRI K. \& M. SANJAPPA (eds.), Fascicles of Flora of India. Fascicle 19 Botanical Survey of India, Kolkata. pp. 64-233.

POWO 2019. Plants of the World Online. Facilitated by the Royal Botanic Gardens, Kew. Available at: http:// www.plantsoftheworldonline.org/ (Accessed on 19.03.2021).

RICHARD A. 1847. Tentamen Florae Abyssinicae seu Enumerotio Plantarum in plerisque Abyssiniae. Volume 1. Parisiis: Arthus Bertrand.

ROXBURGH W. 1832. Flora Indica. Volume 3. Printed for W. Thacker \& Co., Kolkata and Parbury, Allen and Co. London.

SIVARAJAN V.V. \& A.K. PRADEEP 1994. Taxonomy of the Sida rhombifolia (Malvaceae) complex in India. Sida 16(1): 63-78. https://www.jstor.org/stable/41967083

SIVARAJAN V.V. \& A.K. PRADEEP 1996. Malvaceae of of southern Peninsular India: a taxonomic monograph. Daya Publishing House, New Delhi.

STAFLEU F.A. \& R.S. COWAN 1976. Taxonomic literature: a selective guide to botanical publications and collections with dates, commentaries and types. Volume 1: A-G. Second Edition. Bohn, Scheltema \& Holkema Utrecht.

STAFLEU F.A. \& R.S. COWAN 1983. Taxonomic literature: a selective guide to botanical publications and collections with dates, commentaries and types. Volume 4: P-Sak. Second Edition. Bohn, Schletema and Holkema, Utrecht.

TAMBDE G.M., SARDESAI M.M. \& A.K. PANDEY 2020. Sida sivarajanii (Malvaceae): a new species from India. Phytotaxa 428(2): 104-112. https://doi.org/ 10.11646/phytotaxa.428.2.4

TAMBDE G.M., NIMBALKAR V.V., LEKHAK M.M. \& M.M. SARDESAI 2016. Sida pradeepiana sp.nov. (Malvaceae) from India. Nordic Journal of Botany. https:// doi.org/10.1111/njb.01147

TURLAND N.J., WIERSEMA J.H., BARRIE F.R., GREUTER W., HAWKSWORTH D.L., HERENDEEN P.S., KNAPP S., KUSBER W.-H., LI D.-Z., MARHOLD K., MAY T.W., MCNEILL J., MONRO A.M., PRADO J., PRICE M.J. \& G.F. SMITH (eds.) 2018. International Code of Nomenclature for algae, fungi, and plants (Shenzhen Code) adopted by the Nineteenth International Botanical Congress Shenzhen, China, July 2017. Regnum Vegetabile 159, Volume 38. Koeltz Botanical Books, Glashütten. https://doi.org/10.12705/Code.2018

VAN BORSSUM WAALKES J. 1966. Malesian Malvaceae revised. Blumea 14: 1-213.

VOLLESEN K. 1986. The Sida cuneifolia-complex (Malvaceae) in Africa. Kew Bulletin 41(1): 91-98. https:// doi.org/10.2307/4103035

WIGHT, R. \& G.A.W. ARNOTT 1834. Prodromus Florae Peninsulae Indiae Orientalis, Volume 1. Purbury, Allen \& Co., London. 